\title{
Why fees hike is so essential in public/private schools
}

\author{
* Shweta Singh Chandel \\ Assistant Professor, Dr.V.S.I.P.S. Kanpur,U.P.India
}

\begin{abstract}
India is a developing country, Now days parents put more emphasis on educating their bundle of joy in India.They want to enroll their child in renowned school for this they don't mind whether school is private or unaided.After going through all tedious and unwanted process of admission they feel relaxed when their child admitted in these schools. After some time they realize this is their nightmare because of school fee hike and other school expenses.To fulfill the requirement of these schools, mothers also start working, but all these effort are not just enough to fulfill their dreams.
\end{abstract}

The mounting cost of education in recent years has eaten into a major part of the household budget. An Assocham survey showed that $65 \%$ of parents spend more than half their take-home pay on their children's education, extra co-curricular activities placing significant burden on their family budget. According to the survey, parents spending on a single child's education has gone up from Rs 35,000 in 2005 to over Rs 94,000 in 2011 on such items and activities as integral to the school curriculum like fees, transport books, uniform, stationery, building fund, educational trips, extra tuitions and extra-curricular activities. The survey highlights that the rising cost of education, has become a major cause of worry for parents. Majority of parents spend on average more than Rs 18 lakh-20lakh in raising a child by the time their teen graduates from high school.

According to government data, average private expenditure on secondary education in private schools is as high as Rs 893 per month as compared to only Rs 275 per month in government schools primarily due to difference in high tuition fees in private institutions.

Aggregate public spending on education during the 11th Plan period is estimated at Rs1244,797 crore for both the Centre and states taken together. About $43 \%$ of the public expenditure on education was incurred for elementary education, $25 \%$ for secondary education and the balance $32 \%$ for higher education.

About half of the Central government's expenditure was incurred for higher education and the remaining for elementary $(39 \%)$ and secondary $(12 \%)$ education. In the state sector, about $75 \%$ of education expenditure is for school education, of which $44 \%$ is on elementary education and $30 \%$ on secondary education. Public expenditure on secondary education has increased from $0.78 \%$ in $2007-2008$ to $1.05 \%$ in $2011-20$

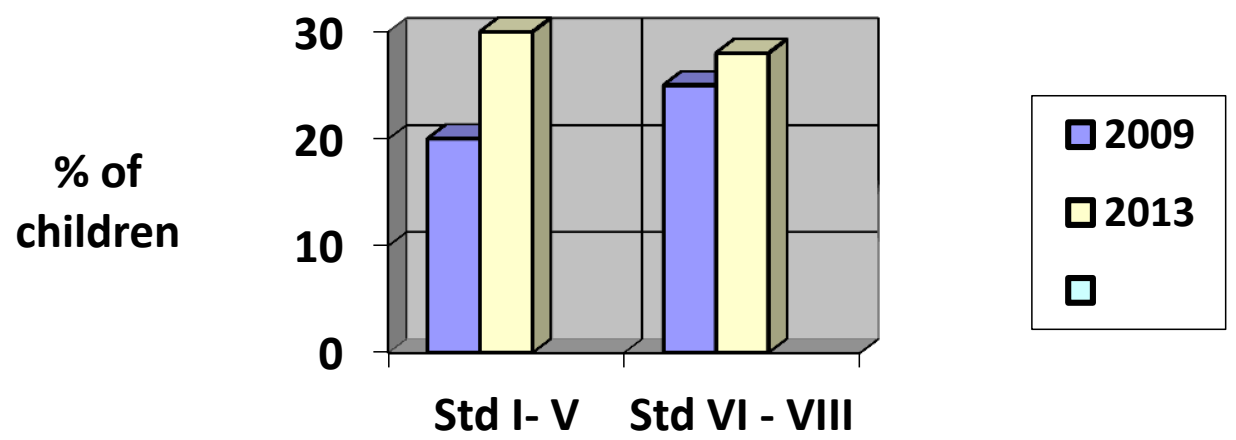

An Assocham survey showed that the percentage of enrolment increases in private schools. An large proportion of children in urban low income areas in private unaided schools .On the basis of a survey where figures taken from three low income zones of Hyderabad, Andhra Pradesh shows that $65 \%$ of children are attending private unaided school. Similar research from North Sahadara, East Delhi shows that out of the 265 schools, private unaided schools made up $66 \%$ of the total schools. A similar survey of schools carried out in Haryana found that private unrecognized schools are operating practically in every locality of the urban centers as well as in rural areas. Indeed it was found that the choice for parents was no longer whether to send their children to school but to 'which type of school' they should be sent. It was estimated that almost $50 \%$ of children attended primary schools were enrolled in the private sector. 
What the law says for the private and unaided schools -Time to time court guides all category of the school .Some Laws and guidelines related to the private/unaided schools are as follows-

1."Private School" means any pre-primary, primary school, secondary or higher secondary school/junior colleges, established, administrated and maintained by any person or body of persons and recognize or approved by competent authority under any law or code of regulation for the time being in force but does not include(i)An aided school ,(ii)A school established and maintained by Central/State a Government or by any local authority, (iii)A school giving or providing or imparting religious instructions along but not any other institutions.

2. Under the" Right of Children to Free and Compulsory Education Act 2009"and the RTE-The school must not' run for the profit'(Model Rules 11(1)).

3. Private Schools shall decide the fees to be charged from the pupil. However such schools shall to get their fees approved from the Executive Committee of Parent Teacher Association before the end of every third month of August during successive academic years or before every third month of march in the same manner for those educational institution for whom the academic years commence on the first day of January. The Parents Teacher Association shall have authority to object that portion of fee which amount to profiteering.

4. In case if there is consensus between the school management and the Parent Teacher Association both shall intimate their consensus to the Divisional fee Regulatory Committee constituted under S.5of the act in prescribed manner for information only.

5. No Private School shall collect any fee in excess of the fee approved or agreed by the of Parent Teacher Association or determined and approved by the Divisional Fee Regulatory Committee or the Divisional committee under this Act .

6. Every fee, contribution or other charges collected from any student by a recognized school, whether aided or not, shall be collected in its own name and a proper receipt shall be granted by school for every collection made by it.

7. Income derived from collection for specific purpose shall be spent only for such purpose.

8.In unaided or Private school for specific purpose, like sports, co-curricular activities, subscription for excursion or subscription for magazines and annual charges by whatever name called, shall be spent solely for exclusive benefit of the student of the concerned school and shall not be included in the savings referred to in sub rule(2).

9. Every recognized unaided school covered by the Act shall maintain the account on the principles of accounting applicable to non-business organization/not-for-profit organization.

10. Every school is required to file a statement of fees every year before the ensuing academic session under section 173) of the said Act with the Director. Such statement will indicate estimated income of the school derived from fees, estimated current operational expenses towards salaries and allowances payable to employees in terms of rule 177(1). Such estimate will also indicate provision for donation, gratuity, reserve fund and other items under rule 177(2) and savings thereafter, if any, in terms of the provision to rule 177(1).

There are so many rules, acts, and laws to define categories of school, guideline for working and fees related issues, it is difficult to explain all of them here. I mention those only which are relevant for the issue.

As previously mentioned different surveys shows that increasing no. of student which are enrolled in private sector. There are lots of rules, acts, laws which are impose on private schools to regulate these schools activities. But time to time parent are complaining about lots of irregularities in school, fees related issues are one of them.

Every year when admission season has set in and parents are a distraught lot. Several private and corporate schools in the major cities have increased fees from anywhere between 30 per cent and 50 per cent for the academic year 2014-15.Parents lament official apathy and the lack of an official framework to regulate fee hikes in private schools. Many have also demanded legislation to check the continuous and irrational hike in fees. Most of the Parent Teacher Associations claimed that-There are no guidelines for finalizing school fees. That's why, every year, it has become a ritual for most private schools to hike fees arbitrarily. Managements do not involve parents in decision-making and the latter are saddled with huge school fees to pay. Parents said they never opposed an annual increase of fee by 10 per cent due to inflationary reasons. But, all major private and corporate schools have hiked fees by 20 to 50 per cent. Parents find it tough because they can't change schools frequently. They also believe that all official orders are only on paper and no attempt is being made to implement them. Instead of such piecemeal offerings, why can't the government come up with a comprehensive legislation to regulate school fee? There should be some logic behind fee hikes.

Parents complain-Some parents also claimed that-

1. Why class I student has been charged Laboratory Fees.

2. Why the Annual Charges taken on per Term basis.

3. Why Pre-Primary child charged Library Fees, Rhyme book, educational CD on every term fees. 
4. Why some Schools charged admission fees from old student in start of every academic year.

5. Why the schools are even putting the synonyms to good use. One of the schools has levied Rs 575 for 'Excursion and Extracurricular' activities and another Rs 575 per year as 'Physical Training and Outings' charge. 6. There is strict ban on capitation fees or donations imposed by the Supreme Court. Why the school charged a big amount as donation and even gave a receipt for the same.

7. Some schools issues receipt on behalf of some charitable society.

8. High Charge of caution money and many more.

\section{Justification of schools}

On the other hand schools says they can justify the yearly fees hike. They have to increase fees to meet expenses such as land rent, water and infrastructure, citing lack of funds to meet the expenses of students admitted under the $25 \%$ quota of the Right to Education Act, and to give incentives to teachers. Schools said they were forced to hike fees as they haven't received the approximately Rs11000 per student reimbursement from the state government for students admitted through the quota.

Most of the schools have no certain criteria for fees hike. But Bala Vidya Mandir follows a system to calculating the increase the fees once or two years. First they calculate the increase like this the total expenses for the last two years plus a 10\% hike for inflation is divided by two, and again divided by school strength, this is again divided by 3 to arrive at the fee per term. According to the school principal, increase of more than $9 \%$ increase per year has a profit motive. But I do not think other schools give any clear criteria for the fee hike.

\section{Suggestions}

There are n number of questions raised by parents from all over India but sadly no authority is there to answer these questions. Here I am not saying that governments are not doing efforts but these are inadequate.

Now it is a time for school to focus on -

1. Improvement of the quality of education.

2. Clean water and better sanitation for students.

3. Better laboratory and library facilities.

4. Teacher must have qualification prescribe by central government.

5. Provision of good salary as well as allowances of teachers.

6. School must provide better learning environment.

7. Student, teacher Ratio.

8. Quotas applied to types of students that are admitted. and so on.

At last I just want to ask one question if The per capita income in the country(India) increased by 6.7 per cent per annum during 2004-05 to 2011-12,How Private Sector school can increase fees more than this percentage.

\section{References}

[1]. Maharastra Educational Institutions(Regulation of Collection of fees)Act 2011.

[2]. Supreme Court Guidelines to unaided Schools: Modern school v. Union of India

[3]. Air 2004 SC 2236:(2004)5 SCC583.

[4]. The Delhi School Education Rules, 1973

[5]. ELEMENTARY EDUCATION AND LITERACY-12th FIVE YEAR PLAN 2012-2017: Department of School Education and Literacy MINISTRY OF HUMAN RESOURCE DEVELOPMENT Government of India, New Delhi .Assocham reports-2011, 2012, 2013. THE ASSOCIATED CHAMBER OF COMMERCE AND INDUSTRIES OF INDIA

[6]. .Dr.Paulin Dixon-Policy Review "RTE Act \& Private School Regulation".

[7]. "Private school fees up nearly 50\%"-M. SAI GOPAL, The Hindu

[8]. EXPRESS NEWS Services

[9]. "Rs 94,000 per year spent on educating a child"-Himanshi Dhawan,TNN ,Jan 9, 2013.

[10]. 'Calculating increases in School Fees'- The Hindu

[11]. 'Two Mumbai schools justify proposed 2014-2015 fee hike'-DNA INDIA, Sunday, 24 November 2013.

[12]. 'Fee hike: HC panel backs inspection in 13 schools to verify financial records'-EXPRESS NEWS SERVICE,NEW DELHI, Sep 1,2013

[13]. '15 per cent fee hike in private schools worries parents'-THE INDIAN EXPRESS, Srinagar, Sun Nov 102013.

[14]. 'India's Inflation has hit school fees the most since 2004': mostlyeconomics.wordpress 